SOŇa KariKová

EDUKACJA MIĘDZYKULTUROWA

2017, nr 1 (6)

ISSN 2299-4106

RUŽENKA ŠIMONIOVÁ-ČERNÁKOVÁ

\title{
National identity of future teachers in Slovakia and Serbia
}

Streszczenie: W artykule porównano konstruowanie tożsamości narodowej przyszłych nauczycieli w Słowacji i Serbii. Pomiaru tożsamości narodowej dokonano przy pomocą skali NAIT (National Identity Scale) ${ }^{1}$. Badana grupa składała się ze 163 studentów narodowości słowackiej i 163 narodowości serbskiej (N - 326), 12\% mężczyzn i 88\% kobiet. W obrębie obu badanych grup, poprzez międzykulturowe analizy porównawcze, dokonano ewaluacji parametrów wyniku surowego ankiety. Wyniki badań wskazują, że przyszli nauczyciele w Słowacji prezentują wyższy poziom i większą stałość tożsamości narodowej. Jednocześnie badanie dowodzi, że świadomość narodowa słowackich przyszłych nauczycieli wzmacniana jest poczuciem patriotyzmu, a serbskich studentów - poczuciem nacjonalizmu. Wyniki omówione zostały w kontekście szkolenia przyszłych nauczycieli, z perspektywy tolerancji i międzykulturowości. Konkluzja zawiera szkic koncepcji edukacji międzykulturowej.

Słowa kluczowe: tożsamość narodowa, tożsamość etniczna, nastawienia etniczne, przyszli nauczyciele, edukacja międzykulturowa

\section{Introduction}

The democratic changes in the post-totalitarian countries of the Eastern Block notably activated the process of ethnical self-awareness, which stimulated the need for a deeper understanding of ethnicity from the perspective of multiple science. The topic of ethnicity studies became a subject for many researches focused on its construction in the new social conditions ${ }^{2}$. However, the accelerating processes of globalization and multiculturalization

1 D. Čorkalo, Ž. Kamenov: Nacionalni identitet $i$ međunacionalna tolerancija. Izveštaj sa VIII ljetne psihologijske škole. Zagreb 1998, Filozofski fakultet.

2 M. Homišinová: Skúmanie miery osobnej identifikácie príslušníkov majority a minority s makrosociálnymi útvarmi. "Človek a spoločnost” 1992, No. 2. 
bring problems concerning different community integration. Due to this, the issues must be faced of finding new forms of unity, currently emphasized by the migration crisis within the EU. That is why many point out that foundations for creating a healthy national identity and openness towards "being different" are mainly based on the educational system. Therefore, the focus is on national identity from the perspective of future teachers, who act as the principal carriers of ethnical attitudes which they (consiously or not) project into their education and training.

\section{The concept of national identity}

Despite many common aspects, national identity and ethnicity cannot be considered as fully identical notions. In general, this is a "problem" of objective and subjective criteria for defining the differences between a nation and ethnicity ${ }^{3}$. However, for the purpose of this paper, these terms will be treated as synonyms, since these differences do not play the key role in the research into the topic. Moreover, it is quite common that these terms are interchanged ${ }^{4}$.

In the times of the constantly growing institutional interconnection and national organization which influences the legislation in individual states, the task of defining national identity is becoming a real challenge ${ }^{5}$. The variability of its conceptualization is also proved by the complex understanding of the term at the level of many disciplines that deal with aspects of ethnicity. However, the perspective of psychological development is the essential basis, as it considers the national identity to be one of the elements of each individual's personal identity. In this context, the basic theoretical scope comes from the theory of social identity, the model of acculturation and developmental theories.

As regards the model of social identity theory by Tajfel and Turner, the individual's identity also includes social identity derived from the perceived membership in a relevant social group ${ }^{6}$. In this sense, national identity can

\footnotetext{
3 A. Heywood: Politologie. Praha 2002, Eurolex Bohemia.

4 E. Gellner: Nacionalizmus. Brno 2003, CDK.

5 M. Denci: Vybrané aspekty pôsobenia jazykových bariér na sociálno-ekonomickú situáciu národnostných menšín. "Sociálne a politické analýzy” 2013, No. 7 (1),
} pp. 18-42.

6 M. Sakač: Struktura nacionalnog identiteta mladih. In: S. Marković (ed.): Dru- 
be considered a part of social identity which is based on the feeling of belonging to a certain ethnic group. The construct of acculturation based on Phinney's theory is understood as changes in cultural attitudes, values and behavior patterns under the influence of interaction between two cultures during a certain time period, all based on two theoretical models ${ }^{7}$. The linear (bipolar) model suggests that ethnic identity and acculturation are mutually incompatible, while the two-dimensional model points out that an individual can be independently connected with both minority and the dominant culture. The developmental theories perceive national identity as a dynamic concept that changes throughout the time and context. These theories are based on Erikson's theory of forming and developing ego-identity ${ }^{8}$. Mareš, for example, provides the opinion of Mc Adams, who postulates identity in connection with human personality as an internalized, developing narrative which integrates the reconstructed past, the perceived present and the imagined future ${ }^{9}$. The concept of national or ethnic identity is generally based on the above characteristics, with the emphasis on the importance of the symbolic and cognitive connection of citizens with their state and is defined as the awareness of being a member of a nationality group, along with the existence of common values, goals and beliefs ${ }^{10}$.

From the perspective of the construction of national identity, the concept must be also mentioned of the primordial model claiming that humans have their ethnic identity embedded since their birth and that they get it as a part of their ethnicity's cultural heritage ${ }^{11}$. Individuals are connected with their ethnicity through their ancestors by common language, history, territory and shared values. On the other side, there is the constructivism model seeing the

štveni odnosi Srba i Hrvata, nacionalni identitet $i$ manjinska prava sa aspekta evropskih integracija. Sombor 2011, Pedagoški fakultet, pp. 107-124.

7 J. S. Phinney: Ethnic Identity in adolescents and adults: Review of research. "Psychological bulletin" 1990, No. 108 (3), pp. 499-514.

8 E. H. Erikson: Dětství a společnost. Praha 2002, Argo.

9 J. Mareš: Pedagogická psychologie. Praha 2013, Portál.

10 R. Šimoniová-Černáková: Vzdelávanie v materinskom jazyku. In: A. Tomanová-Makanová (ed.): Zborník príspevkov z medzi národnej konferencie "Slováci a Srbi história a súčasnost". Nový Sad 2014, Národnostná rada slovenskej národnej menšiny, pp. 321-333.

11 C. Geertz: Primordial and Civic Ties. In.: J. Hutchinson, A. D. Smith (eds): Nationalism. Oxford 1994, University Press. 
ethnic identity as a matter of individual choice - a freely chosen membership in a group based on a subjective decision ${ }^{12}$.

As for the structure of national identity, Phinney describes several elements: (a) self-identification - individual's self-determination as a member of a nation; (b) sense of membership in the ethic group - it varies on a continuum from formal affiliation up to a very strong emotional adherence to the group; (c) attitudes towards affiliation to a group; (d) taking part in the ethnic group's work and life - reflected in the usage of language, in the knowledge of its culture and history, in making friendships and personal contacts with the members of the own nationality, in affiliation to the religion, etc. ${ }^{13}$

\section{Explicit definition of the research aim and questions}

The current global issues caused by the migration surge affect all European countries. As a result of these issues, what may be faced is an increasing number of children who are going to be taught in the educational environment of a European country. That is why the paper focuses on one of the aspects of this topic. It is the construct of future teachers' national identity, which influences the subsequent attitudes (prejudices) towards learners from a different ethnicity. The study has the potential to shed more light on the investigated topic from the perspective of future teachers, a less explored, but due to the current issues a very important part of the population ${ }^{14}$.

The main objective of the research is to identify the differences in constructing national identity between the groups of future teachers from Slovakia and Serbia. The research sample selection is based on: (a) focusing on future teachers, who during their teaching might come into contact with learners from a different ethnic and cultural environment (modern migrants, a country's autonomous minorities); (b) focusing on the countries sharing certain similar historical features that might be reflected in the concept of their national identity. Aiming at the established goal, two research questions

12 V. Bačová: Primordiálny versus inštrumentálny základ etnickej a národnostnej identity. “Československá psychologie” 1997, No. 54 (4), pp. 303-314.

13 J. S. Phinney: Ethnic Identity in adolescents and adults: Review of research. "Psychological bulletin" 1990, No. 108 (3), pp. 499-514.

14 J. Průcha: Multikulturní výchova (teorie - praxe - výzkum). Praha 2001, ISV. 
were formulated: Are there any differences in the perceived level of national identity between Slovak and Serbian respondents? Is it possible to specify more discrete and slighter differences in the content of the national identity construct between the respondent groups?

\section{Methods}

The presented study is an empirical quantitative research. It has a comparative intercultural design. The data were collected using the questionnaire method and were analyzed with SPSS program. Descriptive, as well as inferential statistics were used. The selection of statistical tests was preceded by the data distribution testing. Apart from the statistical significance, the objective significance of the results was also evaluated.

The research sample included 163 students of Slovak nationality and 163 Serbian nationality students $(\mathrm{N}-326)$. The total number within the sample included $12 \%$ of men and $88 \%$ of women. Both groups consisted of students from the Faculty of Education at UMB in Banská Bystrica and the Faculty of Education at UNS in Sombor. The men to women ration was well balanced, which allowed to perform intersexual comparisons. However, this represents an approximate real distribution of men and women among the students future teachers, that is why men were included in the sample. The comparative analyses were subsequently directed towards the topic of intercultural comparisons. All students participated in the research voluntarily.

For measuring national identity, the National Identity Scale NAIT was used $^{15}$. Until now, the scale has been used in Croatia and Serbia. Due to this, the methodology within this study had to be adapted to Slovak cultural conditions, which meant that the questionnaire had to be back-translated. NAIT consists of 27 items. The answers are ranked on a 5 -level scale ( 1 - fully disagree, 5 - fully agree). The questionnaire's minimum score is 27 and maximum score is 135 points. The questionnaire also includes inversion items that have been converted in the data set. The higher the participant's score in the questionnaire, the higher level of his/her national identity. Until now, no stable latent structure was identified within the recorded construct, that is why the questionnaire is considered to be one-dimensional ${ }^{16}$.

15 D. Čorkalo, Ž. Kamenov: Nacionalni identitet $i$ međunacionalna tolerancija. Izveštaj sa VIII ljetne psihologijske škole. Zagreb 1998, Filozofski fakultet.

16 M. Sakač: Struktura nacionalnog identiteta mladih. In: S. Marković (ed.): Društve- 
Reflecting the analysis, the internal consistence was also assessed of the entire questionnaire, for the set of Serbian and Slovak students independently. Within the set of Serbian students, the Cronbach's alpha coefficient equals 0.923; for the set of Slovak students the coefficient value is 0.872 . In both sets the coefficient value was high, proving a very good level of the internal consistency of the whole questionnaire.

\section{Results}

The first step comprised a comparison of groups within the raw scores of the national identity in the NAIT questionnaire. Table 1 presents an overview of descriptive indicators of the "national identity" variable for both student groups.

Table 1. Descriptive indicators of the variable of national identity for both groups

\begin{tabular}{|l|c|c|c|c|c|c|}
\hline & $\mathrm{n}$ & AM & SD & MDN & Minimum & Maximum \\
\hline Slovak students & 163 & 88.97 & 14.71 & 89 & 47 & 132 \\
\hline Serbian students & 163 & 76.11 & 18.69 & 78 & 30 & 119 \\
\hline
\end{tabular}

$\mathrm{n}$ - number of students in the group, AM - arithmetic mean, SD - standard deviation, MDN - median, Minimum/Maximum - minimum and maximum value achieved in the questionnaire

The descriptive indicators clearly prove that Slovak students achieve, on average, a higher score of national identity than the students from Serbia. Serbian students' answers show higher variability. Based on the assessment of the national identity variable distribution within both sets (the variables fulfilled the requirement of normal distribution), the groups were started compared using parametric Student's t-test for two independent selections. The result of this test is presented in Table 2 .

Table 2. Result of the set comparison within the variable of national identity

\begin{tabular}{|l|c|c|c|c|}
\hline & $\mathrm{t}$ & Df & P & $\mathrm{d}$ \\
\hline Final values & 6.640 & 270.7 & 0.000 & 0.765 \\
\hline
\end{tabular}

$\mathrm{t}$ - results of $\mathrm{t}$-test, $\mathrm{df}$ - degrees of freedom, $\mathrm{p}$ - significance value, $\mathrm{d}$ - effect size/ Cohen's d

ni odnosi Srba i Hrvata, nacionalni identitet $i$ manjinska prava sa aspekta evropskih integracija. Sombor 2011, Pedagoški fakultet, pp. 107-124. S. Štrangarić: Odnos religije i nacije - primer studenata u Vojvodini. "Religija i tolerancija" 2014, No. 12 (21), pp. 109-124. 
The t-test results proved a statistically significant difference in the national identity in favor of the Slovak students. The level of objective significance (close to 0.8 - big effect) indicates a real trend in the data that should be addressed. In the conclusion, it is summarized that the assessment of Slovak students prove higher awareness of national identity and that this concept may be considered more consistent in comparison to the students from Serbia.

Due to the existing differences between the student groups in the dimension of national identity, it seems useful to reflect also the factor solutions of the examined dimension in both groups. The findings are assumed to point out more discreet and slighter differences in the contents of the actual national identity construct. We used the exploratory factor analysis (minimum ordinal level of measurement, normal variable distribution, variables are based on one domain). For monitoring the adequacy of its usage, the Keiser-Meyer-Olkin test was applied (correlations between the items in groups were relatively compact) as well as the Bartlett's sphericity test (correlations between the items in groups were significantly different from null). The analyses were conducted using the method of principal components (PCA) with the oblique rotation (from the theoretical point of view, it should be admitted that the individual factors are not independent). The number of factors for the final solution was defined on the basis of the Kaiser criterion (the eigenvalue is higher than 1 ).

Seven factors were identified within the group of Slovak students. The overview of factor solution is presented in Table 3. Further in text, the focus is only on the very first factor (F1), which explained the highest variability of responses from the Slovak students. F1 included 5 items and explained approximately one fourth of the total response variability. The remaining factors formed a much lower percentage of variance. An overview of all factor loadings of the rotated solution is presented in Table 4 . To improve readability, only the factor loadings were indicated with absolute value higher than 0.3 (on the basis of the significance for interpretation).

F1 for the Slovak students was described on the basis of having the feeling of national identity as an enhancer of the need for unity, respect for the own culture and national symbols. The component was named "patriotisms". 
Table 3. Overview of factor solution for the group of Slovak students

\begin{tabular}{|l|c|c|c|}
\hline \multicolumn{1}{|c|}{ Factor } & Eigenvalue & Variance \% & Cumulative \% \\
\hline F1 & 6.846 & 25.354 & 25.354 \\
\hline F2 & 2.421 & 8.967 & 34.321 \\
\hline F3 & 1.762 & 6.528 & 40.849 \\
\hline F4 & 1.436 & 5.318 & 46.167 \\
\hline F5 & 1.189 & 4.403 & 50.570 \\
\hline F6 & 1.153 & 4.272 & 54.842 \\
\hline F7 & 1.033 & 3.825 & 58.667 \\
\hline
\end{tabular}

Table 4. Factor loading of the rotated solution for Slovak students

\begin{tabular}{|c|c|c|c|c|c|c|c|}
\hline \multirow{2}{*}{ Items } & \multicolumn{7}{|c|}{ Factors } \\
\hline & 1 & 2 & 3 & 4 & 5 & 6 & 7 \\
\hline Members of a nation should hold together. & ,763 & & & & & & \\
\hline $\begin{array}{l}\text { Thanks to the rich culture of my nation I feel more } \\
\text { valued, valuable. }\end{array}$ & ,657 & & & & & & \\
\hline I feel proud whenever I hear our national anthem. &, 572 & & & & & & \\
\hline $\begin{array}{l}\text { The feeling of being part of a nation completes me as } \\
\text { a person. }\end{array}$ &, 525 & & & & & &,- 358 \\
\hline $\begin{array}{l}\text { The feeling of unity with one's own nation is one of the } \\
\text { most beautiful feelings people can experience. }\end{array}$ & ,399 & & & ,308 & &,- 336 & \\
\hline $\begin{array}{l}\text { I would like to live as a world citizen, not as a citizen } \\
\text { of a nation. }\end{array}$ & & ,812 & & & & & \\
\hline I consider myself mainly as a world citizen. & & ,741 & & & & & \\
\hline $\begin{array}{l}\text { Human kind acts as the only real human society, that is } \\
\text { why the division into nations is harmful and irrelevant. }\end{array}$ & & ,683 & & & & & \\
\hline $\begin{array}{l}\text { I am a member of the human kind in the first place, } \\
\text { only then of my nation. }\end{array}$ & &, 584 & & & & & \\
\hline It is necessary to teach children to love their nation. & & &,- 765 & & & & \\
\hline $\begin{array}{l}\text { From early age, children should be encouraged to have } \\
\text { "national spirit". }\end{array}$ & & &,- 720 & & & & \\
\hline I am proud of my nation's history. & & &,- 680 & & & & \\
\hline Each society should foster its national ideals. & & &,- 488 & & & & \\
\hline $\begin{array}{l}\text { I consider myself to be a motivated and aware member } \\
\text { of my nation. }\end{array}$ & & &,- 419 & & 307 & ,398 & \\
\hline $\begin{array}{l}\text { A true member of my nation should not make friend- } \\
\text { ships with our enemies. }\end{array}$ & & & &, 759 & & & \\
\hline $\begin{array}{l}\text { Loyalty towards my nation is more important than loy- } \\
\text { alty towards myself. }\end{array}$ & & & &, 581 & & & \\
\hline $\begin{array}{l}\text { People who disregard their own nation deserve disre- } \\
\text { spect. }\end{array}$ & & & &, 501 & & & \\
\hline I am ready to sacrifice my life for my nation. & & & &, 500 & & & \\
\hline
\end{tabular}


continuation of Table 4

\begin{tabular}{|c|c|c|c|c|c|}
\hline $\begin{array}{l}\text { A human without a clear feeling of national identity is } \\
\text { a human being without identity. }\end{array}$ & & ,345 & & & \\
\hline $\begin{array}{l}\text { Even though my nation is small, it includes much more } \\
\text { apt people than other nations. }\end{array}$ & & & ,549 &,- 327 & \\
\hline $\begin{array}{l}\text { Without the feeling of being a member of a nation } \\
\text { I would feel incomplete. }\end{array}$ & ,328 & &,- 448 & & \\
\hline $\begin{array}{l}\text { I do not have the feeling of being a member of a na- } \\
\text { tionality. }\end{array}$ & ,318 & & ,434 & &,- 368 \\
\hline $\begin{array}{l}\text { In all historical conflicts with other nations, my nation } \\
\text { was always right. }\end{array}$ & & & &,- 640 & \\
\hline Emphasizing national symbols is a sign of primitivism. & & & &,- 586 & \\
\hline I find my nationality irrelevant. & & & & &,- 807 \\
\hline My national identity is very important to me. & & & & &,- 691 \\
\hline $\begin{array}{l}\text { I would express my national identity wherever I would } \\
\text { live. }\end{array}$ & 394 & & & &,- 443 \\
\hline
\end{tabular}

Six factors were identified within the group of the Serbian students. The overview of factor solution is presented in Table 5. Further in the text, the focus is only on the very first factor, which explained the highest variability of responses from the Serbian students. F1 included 7 items and explained approximately $35 \%$ of the total response variability. The remaining factors formed a much lower percentage of variance. An overview of all factor loadings of the rotated solution for items is presented in Table 6. To improve readability, again only the factor loadings were indicated with absolute value higher than 0.3 (on the basis of the significance for interpretation).

Under F1, the Serbian students show a very important feeling of "being part of my nation". Comparing to the Slovak students, their factor also indicates a very strong emotional tone, which can be (together with the absence of disrespect for other nations) seen as a feature of "nationalism".

Table 5. Overview of factor solution for the group of Serbian students

\begin{tabular}{|l|c|c|c|}
\hline \multicolumn{1}{|c|}{ Factor } & Eigenvalue & Variance \% & Cumulative \% \\
\hline F1 & 9.458 & 35.029 & 35.029 \\
\hline F2 & 2.355 & 8.724 & 43.753 \\
\hline F3 & 1.624 & 6.016 & 49.769 \\
\hline F4 & 1.176 & 4.357 & 54.126 \\
\hline F5 & 1.094 & 4.051 & 58.177 \\
\hline F6 & 1.060 & 3.928 & 62.105 \\
\hline
\end{tabular}


Table 6. Factor loadings of the rotated solution for F1 with Serbian students

\begin{tabular}{|c|c|c|c|c|c|c|}
\hline \multirow{2}{*}{ Items } & \multicolumn{6}{|c|}{ Factors } \\
\hline & 1 & 2 & 3 & 4 & 5 & 6 \\
\hline I am ready to sacrifice my life for my nation. & ,688 & & & & & \\
\hline People who disregard their own nation deserve disrespect. & ,686 & & & & & \\
\hline $\begin{array}{l}\text { The feeling of unity with one's own nation is one of the most } \\
\text { beautiful feelings people can experience. }\end{array}$ & ,630 & & & &,- 385 & \\
\hline I am proud of my nation's history. &, 599 & & & & & \\
\hline $\begin{array}{l}\text { From early age, children should be encouraged to have "na- } \\
\text { tional spirit". }\end{array}$ &, 526 & & & ,375 & & \\
\hline My national identity is very important to me. & 492 & & & & & \\
\hline $\begin{array}{l}\text { A human without a clear feeling of national identity is a hu- } \\
\text { man being without identity. }\end{array}$ & ,387 & & & & & \\
\hline $\begin{array}{l}\text { Human kind acts as the only real human society, that is why } \\
\text { the division into nations is harmful and irrelevant. }\end{array}$ & &, 757 & & & & \\
\hline I consider myself mainly as a world citizen. & & ,723 & & & & \\
\hline $\begin{array}{l}\text { I am a member of the human kind in the first place, only then } \\
\text { of my nation. }\end{array}$ & &, 721 & & & & \\
\hline $\begin{array}{l}\text { I would like to live as a world citizen, and not as a citizen of } \\
\text { a nation. }\end{array}$ & &, 556 & & & & \\
\hline I do not have the feeling of being a member of a nationality. & & &,- 806 & & & \\
\hline I find my nationality irrelevant. & & ,352 &,- 639 & & & \\
\hline It is necessary to teach children to love their nation. & ,302 & &,- 576 & & & \\
\hline Each society should foster its national ideals. & & &,- 477 & & & \\
\hline $\begin{array}{l}\text { Even though my nation is small, it includes much more apt } \\
\text { people than other nations. }\end{array}$ & & & & ,724 & & \\
\hline $\begin{array}{l}\text { Loyalty towards my nation is more important than loyalty } \\
\text { towards myself. }\end{array}$ & ,364 & & & ,676 & & \\
\hline $\begin{array}{l}\text { A true member of my nation should not make friendships } \\
\text { with our enemies. }\end{array}$ & & & & ,466 &,- 371 & \\
\hline $\begin{array}{l}\text { In all historical conflicts with other nations, my nation was } \\
\text { always right. }\end{array}$ & & & & ,439 & &,- 325 \\
\hline $\begin{array}{l}\text { Thanks to the rich culture of my nation I feel more valued, } \\
\text { valuable. }\end{array}$ & & & & &,- 665 & \\
\hline $\begin{array}{l}\text { Without the feeling of being a member of a nation I would } \\
\text { feel incomplete. }\end{array}$ & & & & &,- 636 & \\
\hline Members of a nation should hold together. & & & & &,- 618 & \\
\hline $\begin{array}{l}\text { The feeling of being part of a nation completes me as a per- } \\
\text { son. }\end{array}$ & & & & &,- 595 & \\
\hline I feel proud whenever I hear our national anthem. & ,330 & & & &,- 592 & \\
\hline I would express my national identity wherever I would live. & & & & &,- 546 & \\
\hline Emphasizing national symbols is a sign of primitivism. & & & & & & ,711 \\
\hline $\begin{array}{l}\text { I consider myself to be a motivated and aware member of my } \\
\text { nation. }\end{array}$ & & &,- 380 & & & ,455 \\
\hline
\end{tabular}


Having a closer look at the factor solutions in both sets, some differences can be spotted. A match can only be found in Factor 2, which includes 4 items with the formulation opposing the national identity and oriented more on identification with a community wider than a nation (these statement also acted as inverted items and this score was converted). This factor can be called global citizenship.

\section{Discussion}

Both research groups had a common feature - the dissolution of their common states (Czechoslovakia and Yugoslavia). Even though they did not witness this process themselves, it was assumed that certain remnants transposed by the generation of their parents or grandparents, the atmosphere in the society, as well as the media, could influence their national identity. Taking into account the results, two summary conclusions can be formulated: (1) The Slovak students - future teachers prove higher national identity awareness and are more consistent in their attitudes towards the topic. The construct of national identity is mainly encouraged by patriotic feelings. (2) Comparing to that, the construct of national identity of the Serbian future teachers is rather connected with nationalism.

Although patriotism and nationalism are the most frequently investigated and discussed aspects of ethnicity, the difference between these two terms is still not entirely clear. The authors are still not fully consistent in opinions on how much these two terms overlap. Kosterman and Feshbach believe that patriotism is an affection for one's own state and can act as one of the components of nationalism. Another component of nationalism is the negative internationalism (negative attitudes towards other states), and some authors claim that these two components can act independently ${ }^{17}$. Patriotism can be understood as love for the state and loyalty to national values, whereas nationalism is seen as a non-critical acceptance of national, state and political authorities combined with the faith in the dominant position and superiority of one's own nation ${ }^{18}$. Reykowski presents two types of patriotism. The first one is the "well-inten-

17 S. Radojčić: Identitet i tradicija. In: S. Marković (ed.): Društveni odnosi Srba i Hrvata, nacionalni identitet $i$ manjinska prava sa aspekta evropskih integracija. Sombor 2011, Pedagoški fakultet, pp. 125-136.

18 V. Mihić: Da li smo mi evropljani? Povezanost $i$ korelati evropskog $i$ nacionalnog identiteta. "Psihologija” 2009, No. 42 (2), pp. 203-220. Doi: 10.2298/PSI0902203M. 
tioned" patriotism, defined as the interest to create a good reputation of one's own state in compliance with the interests of other nations. The second is the "hostile" patriotism including antagonistic attitudes towards other states ${ }^{19}$.

Although this area does not show full terminological consensus, on the basis of the comparison of groups within the factor solution of the construct, it can be believed that Slovak participants show a higher level of patriotism. This is particularly related to emphasizing the respect for the nation ("The feeling of being part of a nation completes me as a person"), its culture ("Thanks to culture I feel more valued") or state symbols ("I feel proud whenever I hear our national anthem"). In the case of Serbian students, nationalism can be noticed due to a certain degree of irrationality or indiscrimination resulting from stronger emotionality ("People who disregard their own nation deserve disrespect"; "The feeling of unity with nation is one of the most beautiful feelings") and even fatality in their attitudes ("I am ready to sacrifice my life for my nation", "A human without a clear feeling of national identity is a human being without identity").

The differences in the construct of national identity found between the Slovak and Serbian students - future teachers can be explained on the basis of several facts. The Slovak Republic is an EU member state, it is inhabited by a relatively low and stabilized number of ethnic minorities and it underwent a peaceful dissolution of the common state. On the other hand, the Republic of Serbia is not a member of the EU, it has a higher number of inhabitants coming from ethnic minorities within its territory and the dissolution of the common state was very harsh and resulted in a war conflict. According to Mihić, the topic of national identity in SFR Yugoslavia became prominent particularly during the dissolution of the common state, bringing a series of issues and almost inexplicable situations, in which many neighbours became enemies "only" due to different nationality ${ }^{20}$. Radojčić believes that these events might have even stimulated some kind of national mythology $y^{21}$. His opinion supports our findings and his interpretation, according to which the Serbian students perceive the topic of nationality in an emotional, rather than in a rational (cognitive) way. Excessive emotionality is probably also the reason of a lower level of currently experienced national identity or its consistency, because the emo-

\footnotetext{
19 Ibid., pp. 203-220.

20 Ibid.

21 S. Radojčić: Identitet i tradicija. In: S. Marković (ed.): Društveni odnosi Srba i Hrvata, nacionalni identitet $i$ manjinska prava sa aspekta evropskih integracija. Sombor 2011, Pedagoški fakultet, pp. 125-136.
} 
tions connected with the war conflict have gradually faded away - particularly within the generation that did not directly witness the war. However, it would be suitable to verify our interpretation by further research.

Apart from the summary results presented above, the methodological findings should be also summarized which were derived from the presented analyses. Although the factor solution in our study did not primarily lead towards searching for steady latent variables within the measured construct (as a standard when interpreting factor solutions), the assumption seems to be confirmed that the questionnaire should be used in its original form solely as a one-dimensional measuring tool ${ }^{22}$. This was confirmed by the significant differences in the item analysis (mutual correlation item matrix - it is not presented here but was performed), but also by the results of the exploratory factor analysis within the research sets ${ }^{23}$. On the other hand, the finding which concerns the identified match within the factor, named "global citizenship", could be used to create a more universal measuring tools (a culture free questionnaire).

In association with the emphasis on the affective element of the national attitudes, the emphasized primordial link should be indicated within the Serbian students, which addresses the emotional rather than the rational parts of human mind, in comparison to the instrumental approach represented by the Slovak students, with their pragmatic, situational and adjustable aspects of ethnicity ${ }^{24}$. When speaking of future teachers, the elements of stronger affectivity in the context of national identity, cannot be used as the optimal primary basis for ethnic attitudes being shared within the educational setting. The intensified affective-assessment element of attitudes creates a "breeding ground" for teachers' ethnic and racial stereotypes which come into being in children already in their pre-school age and which further develop during childhood and adolescence. Since schools act as the essential socializing factors, these finding should not be neglected ${ }^{25}$. Therefore, the opinions of

22 M. Sakač: Struktura nacionalnog identiteta mladih. In: S. Marković (ed.): Društveni odnosi Srba i Hrvata, nacionalni identitet $i$ manjinska prava sa aspekta evropskih integracija. Sombor 2011, Pedagoški fakultet, pp. 107-124.

23 S. Štrangarić: Odnos religije i nacije - primer studenata u Vojvodini. "Religija i tolerancija" 2014, No. 12 (21), pp. 109-124.

24 V. Bačová: Primordiálny versus inštrumentálny základ etnickej a národnostnej identity. "Československá psychologie" 1997, No. 54 (4), pp. 303-314.

25 D. Matsumoto: Culture and Psychology. Brooks/Cole 1996, Publishing Company. J. Průcha: Multikulturní výchova (teorie - praxe - výzkum). Praha 2001, ISV. 
Vančíková should be agreed - she emphasizes how important it is to focus on the topic of ethnic attitudes during the training of future teachers to prevent an increase in ethnic prejudices ${ }^{26}$. These findings should be also reflected when creating university curricula at faculties of education - with focus on multiculturalism, education towards tolerance, multicultural communication and negotiation, and on intercultural education.

\section{Conclusion - the basis for a concept of intercultural education}

The topic of intercultural education comes from the need to widen the knowledge on intercultural communication caused by the difficult global social and political situation we face nowadays. The situation issues from wide social changes that have been happening in the last decades in Europe, as well as all over the world. These changes are reflected in dynamic long-term social and political processes, mainly the globalization - i.e. interconnection of worlds, mutual dependence of societies and their influence on each other. The globalization has caused that intercultural understanding and intercultural competences have become much more important, because they help to resolve negative effects of globalization and of the "different" lifestyle of societies. These comprise cultural, sociocultural and ethnic misunderstandings - the main causes of the most evident problems - e.g. discrimination, racism and prejudice. Intercultural communication also allows us to solve complex global socio-political and economic problem situations (such as terrorism and mass migration) with commonly shared solutions of the international community.

In the region of Slovakia and Serbia (as an EU membership candidate), the consequences of direct globalization can be seen mainly in the context of the European Union. Migration processes, increased private and business mobility, and the clash of cultures bring many positive, but also negative effects. These processes naturally intensify the intercultural dialogue of the EU citizens at the individual level, as well as the dialogue between the EU member states and organizations at the national, supranational, as well as institutional level. The spotlight on intercultural competences is based on the situations, handling of which requires deeper knowledge and more education in the area of intercultural competences, as presented in several international

26 K. Vančíková: Multikultúrna výchova a jej miesto v súčasnej škole. Banská Bystrica 2013, PF UMB. 
research papers. For example, within the EU the intercultural communication or intercultural dialogue have a special status with long-term history reaching as far back as $1970 \mathrm{~s}^{27}$. As regards the recent years, it was in 2005 when the third summit of the EU countries' presidents and governments identified the intercultural dialogue (including its religious dimension) as one of the main tools for implementing awareness, understanding, peacemaking and tolerance, as well as preventing conflicts and securing integration and unity within the society. This dimension was completed within the key document on intercultural dialogue - in "Faro" Declaration on the Council of Europe's Strategy for Developing Intercultural Dialogue, which was adopted by the EU states' ministers of culture. After that, another key document went into preparation, namely the Council of Europe's "White Paper on Intercultural Dialogue: Living Together As Equals in Dignity" ${ }^{28}$. This document:

- identifies how to encourage a more vivid intercultural dialogue between cultures within and among the societies within Europe and between Europe and its neighbours;

- highlights the importance of the intercultural dialogue for the European society to prosper during many upcoming years;

- emphasizes the need of intercultural competences which on the basis of the document are not acquired automatically and which need to be learned, practiced and maintained throughout the entire life.

Public authorities, civil society organizations and other providers of education should support the development of intercultural dialogue at all levels, design and introduce syllabi and curricula concerning intercultural dialogue competences at all levels of education, including the education of lectors and teachers.

Therefore, it is necessary to constantly deepen the knowledge in the area of education on intercultural communication as such - e.g. the above mentioned "White Book" document suggests that during the data collection and consultation on the intercultural dialogue and communication, the authors were not entirely sure what "intercultural dialogue" actually means (consultations were held with steering committees, members of the EU parliament

27 Council of Europe. The presidency of the Council of the EU: A rotating presidency. http://www.consilium.europa.eu/en/council-eu/presidency-council-eu/ (access: 4.05.2016).

28 Council of Europe. White paper on intercultural dialogue: Living together as equals in dignity. Strasbourg: Launched by the Council of Europe Ministers of Foreign Affairs at their $118^{\text {th }}$ Ministerial Session. http://www.coe.int/t/dg4/intercultural/ (access: 20.11.2009). 
and congress, local and regional authorities, non-government organizations and international institutions, as well as all EU member states). This is probably also caused by the absence of an unambiguous definition that could be applied to all specific situations in different contexts of using intercultural dialogues and communication. Another reason is that respondents showed ambiguity in terms of the real meaning of intercultural dialogue in practice. Partially, this was also due to the fact that the discourse on this discipline is still only taking its final shape, key words are still shifty and ambiguous.

The main institutional bodies in the area of educational policy include UN and the Council of Europe; these institutions also prepared the concept of intercultural education. For the basic orientation in the approaches to intercultural education, the Council of Europe's approach should be mentioned. The profile of intercultural education was based on the project "Learning to Live Together" introduced in 1996 by the International Commission of Education for the $21^{\text {st }}$ Century. This profile of intercultural education includes six intercultural education processes (Figure 1):

- Education for Civility

- Peace Education

- Education for Democratic Citizenship

- Intercultural Education

- Global Education

- Education for Social Capital ${ }^{29}$.

The presented profile of intercultural education includes a whole series of aspects coming from the overall goal of the "learn to live together" process and these can be considered as complex objectives within intercultural education. These aspects include:

- Cross-fertilization (learn and use each other)

- Cultural relativism (equality of cultures, no discrimination)

- Multiple identities (development of personal identity influenced by more than one culture)

- Diversity/pluralism (no discrimination and exclusion, but a creative way of using plurality and mutual acceptance of diversity)

- Interaction (joint learning, negotiations within intercultural questions and conflicts)

29 Council of Europe. Intercultural competencies for all: Preparation for living in a heterogeneous world. http://www.coe.int/t/dg4/education/pestalozzi/Source/Documentation/Pestalozzi2_EN.pdf (access: 15.03.2103). 
- New collective identities (European citizenship, global citizenship)

- Cultural hybridization (developing values, attitudes and ways of coexistence using cultural pluralism)

- Ecumenical/interfaith dialogue (communication within religious communities)

- Cooperative learning (learning from each other, project works etc.).

It is obvious that intercultural education requires not only a knowledge of various cultural backgrounds of the intercultural dialogue participants, but also the development of knowledge and skills which are going to prepare the participants of the intercultural dialogue for negotiating their mutual otherness and diversity. In this context, the social psychologist Krappmann describes a set of several competencies and attitudes for negotiating identity in the society being further developed towards intercultural education, as follows:

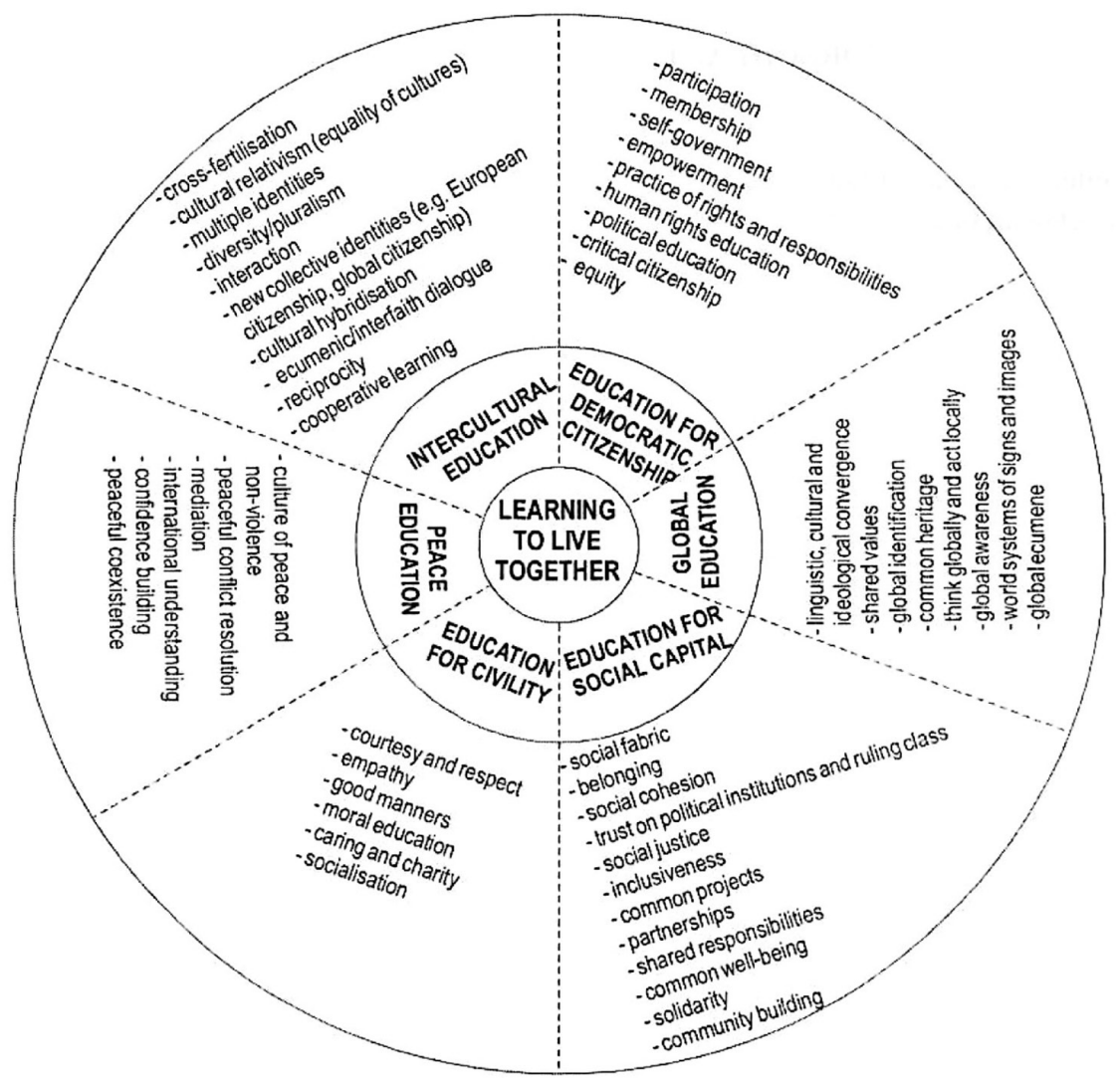


- Empathy

- Role distance and decentering

- Tolerance of ambiguity

- Awareness of self and representation of identity

- Emotional openness

- Multiperspectivity

- Relinquishing centre stage

- Language competence ${ }^{30}$.

These competences were the foundation for the "rules" of communication in multicultural groups:

- Rule 1: Refrain from automatic interpretations, assumptions and judgments

- Rule 2: Step outside your frame of reference

- Rule 3: Be ready to explain the obvious

- Rule 4: Listen and ask questions

- Rule 5: Apply your skill of critical thinking

- Rule 6: Exchange and discuss value judgments

- Rule 7: Focus on solutions, not problems.

The above rules act as a basis for conceiving subjects in various university curricula focused on training of future teachers. The findings of the presented research indicate that significant differences, also in perceiving national identity by two groups of respondents coming from two different countries (Slovakia - Serbia), may be connected with the particular country - its history, culture, political situation, and to a certain extent with its EU membership status.

\section{Acknowledgments}

The paper was written with the grant support from a project of the Ministry of Education, Science, Research and Sport of the Slovak Republic titled Influence of Education and Socio-Cultural Factors on the Formation of National Identity.

\section{Bibliography}

Bačová V.: Primordiálny versus inštrumentálny základ etnickej a národnostnej identity. "Československá psychologie" 1997, No. 54 (4).

30 L. Krappmann: Soziologische Dimensionen der Identität. Stuttgart 1969, Klett. 
Čorkalo D., Kamenov Ž.: Nacionalni identitet $i$ međunacionalna tolerancija, Izveštaj sa VIII ljetne psihologijske škole. Zagreb 1998, Filozofski fakultet. Council of Europe. Intercultural competencies for all: Preparation for living in a heterogeneous world. http://www.coe.int/t/dg4/education/pestalozzi/ Source/Documentation/Pestalozzi2_EN.pdf (access: 15.03.2103).

Council of Europe. The presidency of the Council of the EU: A rotating presidency. http://www.consilium.europa.eu/en/council-eu/presidency-council-eu/ (access: 4.05.2016).

Council of Europe. White paper on intercultural dialogue: Living together as equals in dignity. Strasbourg: Launched by the Council of Europe Ministers of Foreign Affairs at their $118^{\text {th }}$ Ministerial Session. http://www.coe. int/t/dg4/intercultural/ (access: 20.11.2009).

Denci M.: Vybrané aspekty pôsobenia jazykových bariér na sociálno-ekonomickú situáciu národnostných menšín. "Sociálne a politické analýzy" 2013, No 7(1).

Erikson E. H.: Dètství a společnost. Praha 2002, Argo.

Geertz C.: Primordial and Civic Ties. In.: J. Hutchinson, A. D. Smith (eds): Nationalism. Oxford 1994, University Press.

Gellner E.: Nacionalizmus. Brno 2003, CDK.

Heywood A.: Politologie. Praha 2002, Eurolex Bohemia.

Homišinová M.: Skúmanie miery osobnej identifikácie príslušníkov majority a minority s makrosociálnymi útvarmi. "Človek a spoločnost” 1992, No. 2. Krappmann L.: Soziologische Dimensionen der Identität. Stuttgart 1969, Klett. Mareš J.: Pedagogická psychologie. Praha 2013, Portál.

Matsumoto D.: Culture and Psychology. Brooks/Cole 1996, Publishing Company.

Mihić V.: Da li smo mi evropljani? Povezanost $i$ korelati evropskog $i$ nacionalnog identiteta. "Psihologija" 2009, No. 42 (2). Doi: 10.2298/PSI0902203M. Phinney J. S.: Ethnic Identity in adolescents and adults: Review of research. "Psychological bulletin" 1990, No. 108 (3).

Průcha J.: Multikulturní výchova (teorie - praxe - výzkum). Praha 2001, ISV. Radojčić S.: Identitet i tradicija. In: S. Marković (ed.): Društveni odnosi Srba i Hrvata, nacionalni identitet $i$ manjinska prava sa aspekta evropskih integracija. Sombor 2011, Pedagoški fakultet.

Sakač M.: Struktura nacionalnog identiteta mladih. In: S. Marković (ed.): Društveni odnosi Srba i Hrvata, nacionalni identitet i manjinska prava sa aspekta evropskih integracija. Sombor 2011, Pedagoški fakultet. 
Šimoniová-Černáková R.: Vzdelávanie v materinskom jazyku. In: A. Tomanová-Makanová (ed.): Zborník príspevkov z medzi národnej konferencie "Slováci a Srbi - história a súčasnost". Nový Sad 2014, Národnostná rada slovenskej národnej menšiny.

Štrangarić S.: Odnos religije i nacije - primer studenata u Vojvodini. "Religija i tolerancija" 2014, No. 12 (21).

Trevisani D.: Negoziazione interculturale: Comunicare oltre le barriere culturali. Milan 2005, Franco Angeli.

Vančíková K.: Multikultúrna výchova a jej miesto v súčasnej škole. Banská Bystrica 2013, PF UMB.

\title{
National identity of future teachers in Slovakia and Serbia
}

\begin{abstract}
The paper is focused on the comparison of the national identity construct between future teachers in Slovakia and Serbia. The National Identity Scale NAIT was used for measuring national identity ${ }^{31}$. The research sample included 163 students with Slovak nationality and 163 Serbian nationality students (N 326). The total number included $12 \%$ men and $88 \%$ women. Within both examined groups, the intercultural comparison analyses evaluated the parameters of the raw score from the questionnair. The research findings indicate that the future Slovak teachers show higher level and consistency of national identity. At the same time, the research proves that future Slovak teachers' national awareness is encouraged mainly by the feeling of patriotism, Serbian students are more stimulated by the feeling of nationalism. The results are discussed in the context of future teachers' training from the perspective of tolerance and multiculturalism. The conclusion provides a draft of an intercultural education concept.
\end{abstract}

Key words: national identity, ethnic identity, ethnic attitudes, future teachers, intercultural education

Translated by Soňa Kariková, Ruženka Šimoniová-Černáková

31 D. Čorkalo, Ž. Kamenov: Nacionalni identitet $i$ međunacionalna tolerancija. Izveštaj sa VIII ljetne psihologijske škole. Zagreb 1998, Filozofski fakultet. 